\title{
Hermeneutics of Teacher Education: An Inclusion-Based Model
}

\section{Narges Nouri ${ }^{1}$ \& Ramin Rahimy ${ }^{1 *}$}

* Correspondence:

Rahimy49@yahoo.com

1. Department of English Language,

Tonekabon Branch, Islamic Azad

University, Tonekabon, Iran

Received: 7 September 2020

Revision: 22 October 2020

Accepted: 30 November 2020

Published online: 20 December 2020

\begin{abstract}
The present study aimed to investigate the concept of "Teacher Education" from a hermeneutic point of view. This view was selected since there were rare cases in the whole literature related to teacher education. On the other hand, defining a hermeneutic model could be expected to provide a more objective and tangible of teacher education nature and its configuration in the minds of those who directly deal with or discuss it. The main question for which this study tried to find an answer was whether it was possible to present a hermeneutic model for giving an operational definition to teacher education. To answer the question, the study followed a survey-qualitative methodology: first the concept of teacher education was investigated through archival scrutiny and its definition deficiencies were determined. Next, the same procedure was followed for the hermeneutics concept. The data of the study were analyzed via non-statistical comparative analysis, and it was concluded that it was possible to define teacher education hermeneutically; however, the vastness of the issue needed more survey.
\end{abstract}

Keywords: : $\underline{\text { curriculum}}, \underline{\text { hermeneutics, }}$ teacher education, teacher educator identity 


\section{Introduction}

Teacher education is a field of study that has increasingly come under scrutiny in recent times as the expectations for the teaching workforce and the hopes for advancement in school learning are so often tied to the perceived 'quality' of initial teacher education. It could reasonably be argued that such attribution is as a consequence of a particular conception of teaching and learning that ostensibly portrays them as existing in a direct 'cause and effect' short-term, immediately measureable, and linear relationship. As a consequence, although perhaps not always stated as such, telling as teaching and listening as learning (Loughran, 2010) persist. As a consequence, school teaching and learning is simplistically portrayed as a 'banking model' (Freire, 1972), through which 'rate of return' and 'substantive interest' are linked to curriculum certainty delivered through transmissive teaching approaches (Barnes, 1976) designed to mitigate variability. Not only does such a situation cloud the reality of the nature of schooling but it also leads to confusion about that which is reasonable to expect of pre-service teacher education. According to Mehrvarz Bahambari and Rahimy (2016), quoting from Bransford et al. (2000), many people who had difficulty in school might have prospered in their learning, and had the new ideas about effective instructional practices been available at the time.

Hoban (2005) described two purposes of teacher education that he considered needed to be recognized, and appropriately responded to, in structuring a meaningful teacher education program; they were to (i) help pre-service teachers to learn about teaching because a connected program enables them to engage in building their own knowledge; and, (ii) promote a point of view that teaching is a complex profession influenced by many interconnected factors (Hoban, 2005, p.2). In addition, teacher education should be held such that it is purposefully designed to create a pedagogic environment in which students of teaching can experience the challenge, and are supported in further developing understandings of, and approaches to, teaching that challenge: 'telling as teaching' and 'listening as learning' (ibid: Hoban, 2005).

\section{Review of the Literature}

The literature behind the hermeneutics as well as the concept of teacher education can be presented under three main subtitles, namely, "The Beginning of Hermeneutics", "Hermeneutics and the Prejudice against Prejudice" and "The Social Turn." These three literature concepts have been discussed below before getting into the main concepts of the study.

\subsection{The Beginnings of Hermeneutics}

Hermeneutics has a long history, yet remains relevant. Prior to the Protestant Reformation, textual interpretation, including early Christian and Talmudic traditions, was primarily directed to biblical exegesis. Reformation-era hermeneuticians countered the widespread belief that a central authority, Church or State, governed meaning. This shift to regarding interpretation as democratic and heterogeneous has had lasting impact on education. For the first time individuals themselves were understood to be capable of deriving textual meanings, an idea that formed the basis of reader response theories in the twentieth century (Rosenblatt, 1938, 1978).

The word Hermeneutics is originated from the Latinized version of Greek word "hermeneutice." It becomes a part of language in 17th century, but its base is philosophical. It is said that even Plato used this term in his famous and ever green "Dialogues." He treated it as knowledge of Sophia. According to Stanford Encyclopedia of Education, "the term hermeneutics covers both the first order art and the second order theory of understanding and interpretation of linguistic and non-linguistic expressions." This is not a new theory. It is dated back to Greek Mythology and further in the Middle Ages and the era of Renaissance. It is basically treated as a part of Biblical studies.

A complete transformation of the discipline of hermeneutics was made by Martin Heidegger the 1920s. In Heidegger's view, "hermeneutics is not a matter of understanding linguistic communication, nor is it about providing a methodological basis for the human sciences." Hermeneutics is about the most fundamental conditions of man's being in the world. Yet Heidegger's turn to ontology is not completely separated from earlier hermeneutic philosophies. Such a philosopher saw hermeneutics as one of the bases for interpretation (Schleiermacher, 1938).

\subsection{Hermeneutics and the Prejudice against Prejudice}

The death of Hans-Georg Gadamer in March 2002, at the age of 102, marked the end of a distinguished career that only really began when he was sixty years old. The publication, in 1960, of his book "Truth and Method" brought philosophical hermeneutics to a wide audience. It was closely in tune with the post-modern spirit of the time, in 
undermining objectivist notions of "knowledge" and "understanding" that had predominated since the onset of the scientific revolution in the seventeenth century and on through the Enlightenment. Hermeneutics has its origins with such intellectual giants as Friedrich Schleiermacher (1768-1834) and the concerns raised by the interpretation of ancient texts, particularly Biblical texts. Gadamer's account of hermeneutic theory takes it beyond the confines of textual interpretation to embrace all toms of knowing and understanding, in all areas of inquiry (Dilthy 1998). One of his central insights was that all acts of reasoning and knowing involve prejudice and prejudgment, and, as Richard Bernstein explains, this is indeed a very radical thesis: he argued if Gadamer is right in claiming that not only understanding but all knowing "inevitably involves some prejudice" then it is difficult to imagine a more radical critique of Cartesianism, as well as the Enlightenment conception of human knowledge. For in these traditions there are sharp dichotomies between reason and prejudice, or between knowledge and prejudice (Bernstein, 1983, p. 128).

\subsection{The Sociocultural Turn}

The epistemological stance of the sociocultural turn defines human learning as a dynamic social activity that is situated in physical and social contexts, and distributed across persons, tools, and activities (Rogoff, 2003; Salomon, 1993; Vygotsky, 1978; Wertsch, 1991). Although rooted in divergent intellectual traditions, several compatible theories have helped explicate this turn. Theories of situated cognition argue that knowledge entails lived practices, not just accumulated information, and the processes of learning are negotiated with people in what they do, through experiences in the social practices associated with particular activities (Chaiklin \& Lave, 1996; Lave \& Wenger, 1991; Wenger, 1998).

Moreover, social activities are regulated by normative ways of reasoning and using tasks and other resources in collective activity, or what Lave and Wenger (1991) have termed a community of practice. Thus, the knowledge of the individual is constructed through the knowledge of the communities of practice within which the individual participates.

Sociocultural theories also argue that the way in which human consciousness develops depends on the specific social activities in which people engage. However, in order to understand human learning, or higher cognitive development, one must look at the social activities that the individual engages in and see how they reappear as mental activities in the individual (Lantolf, 2000; Lantolf \& Appel, 1994; Leont'ev, 1981; Vygotsky, 1978, 1986; Wertsch, 1985, 1991). Learning, therefore, is not the straightforward appropriation of skills or knowledge from the outside in, but the progressive movement from external, socially mediated activity to internal mediational control by individual learners, which results in the transformation of both the self and the activity. And because social activities and the language used to regulate them are structured and gain meaning in historically and culturally situated ways, both the physical tools and the language practices used by communities of practice gain their meaning from those who have come before. Critical social theories support the notion that social activities simultaneously reflect, create, and recreate historically situated ways of knowing, social relations, and material conditions (Bourdieu \& Passeron, 1977; Foucault, 1980; Habermas, 1998).

\subsection{Research Question of the Study}

The qualitative nature of the study did not necessitate the researchers to make any hypothesization, and as a result, there was no "Hypothesis Testing." This study was an attempt to suggest an answer to the following research question based on the literature reviewed:

RQ: Can a hermeneutic model for giving an operational definition to teacher education be given?

\section{The Study (Methodology)}

This study has followed a qualitative methodology. There were no human participants in this study; rather, the whole material used here included a scrutiny among variety of sources regarding the concepts of hermeneutics and teacher education. The outcome of such a scrutiny was access to different main concepts of hermeneutics that could be attributed to teacher education. The summary of the qualitative methodology is in the Table (1) below: 
Table 1 . The summary of the methodology of the study

\begin{tabular}{llllll}
\hline Research Study & Design & Methodology & Sampling & Logitudinal & Model-Making \\
\hline Review & Qualitative: & Descriptive: & Non-Human: & No & Yes \\
& Source Survey & Primary/Secondary & Classification & & \\
& & sources & Concepts & & \\
& + & & \\
& & & \\
& & & & \\
& & & & \\
& &
\end{tabular}

\subsection{Concepts from the Methodology}

\subsubsection{Teacher Educator Identity}

There has been quite a flurry of work in recent times around teacher educator identity (for example, Ben-Peretz, Kleeman, Reichenberg, \& Shimoni, 2013; Boyd, Harris \& Murray, 2011), all of which illustrates that being a teacher educator is much more than 'being a teacher teaching in a different context.' In fact, Murray and Male's (2005) research into teacher educator identity found that the transition from school teacher to teacher educator took at least 3 years. For instance, being a writing teacher is different from being trained for teaching it since the teacher educator should learn a bit more about writing like a student because writing seems to be a complex skill to master (Nashta Rahimi \& Rahimy, 2017). Further, according to Haghighi and Rahimy (2017), quoting from Pourhossein Gilakjani (2012), in teaching pronunciation, teachers should be pronunciation coaches as well as teachers.

In a volume on international teacher education, Darling-Hammond and Lieberman (2012) posed four dimensions for comparison: recruitment; initial preparation; induction; and ongoing professional development. The historical perspective allows us to consider how and why these dimensions were constructed. Rather than the result of strictly functional decisions based on a nation's "needs," teacher education is a social and political construction. Understanding historical contexts prevents simplistic recommendations for change, such as borrowing policies and practices from higher-achieving countries ("Just do what Finland does!").

\subsubsection{Structure of Teacher Education}

Governments mostly authorize universities throughout the world to structure and organize teacher education programs. However, colleges, normal schools, vocational schools, and alternative certification programs also are involved as teacher education providers within various country profiles. In the forthcoming sub-section, attention will focus specifically on the different ways teacher education programs can be organized within different academic milieus in the same country.

How politically shaped and vitally important the structure of teacher education is considered internationally. If the structures of teacher education become too diffuse - as in the Houston, Texas example, additional teacher attrition/retention and overall teacher quality problems will result. Likewise, if the structures within teacher education programs are not cohesive - as per the Bergen, Norway model, prospective teachers may experience chasms arising from the delivery of their teacher preparation programs. Internationally, citizens must champion defensible, cohesive structures of teacher education that work productively inside-out (i.e., University of Bergen, Norway) and outside-in (i.e., Houston, TX, USA).

\subsubsection{Teacher Education Curriculum}

It has revisited the purpose of teacher education in the light of different views of teacher professionalism and the changing and complex nature of teaching in the twenty-first century. Contradictory trends were identified with views ranging from a broad perspective of the teacher as a "professional" who makes decisions in curriculum development through to a more restrictive view of teacher as a doer or technician who implements, in a rather simplistic and rigid way, external curriculum impositions in light of an outcome-oriented view, sometimes identified as a set of narrow standards to be met. Thus the definition of standards and/or competences in ITE internationally is associated with a diversity of meanings varying from a more instrumentalist and narrower view of standards and competences towards a more flexible orientation. 
Teaching practice and research are two crucial elements which need long term commitment and solutions require strong collaboration between schools and universities. In so doing, it may well lead to challenging existing teaching professional cultures and foster more collaboration. A redefinition of university and school roles with a growing emphasis on strong, coherent and supportive partnerships is clearly at the heart of challenging the binary of theory and practice and might be possible through a research-based design.

\subsubsection{The Practicum}

Learning in practice does not just happen on its own ... it is important to recognize that practice alone does not make perfect or even good performance. Opportunities to connect practice to expert knowledge must be built into learning experiences for teachers (Darling-Hammond \& Bransford, 2005).

The high level of scrutiny of the practicum itself as initial teacher education institutions, schools, and policy makers tussle over the most appropriate ways to link theory and practice. It is interesting to trace the documentation of practicum issues and innovations over the past century, beginning with Dewey's (1904) identification of differences in perceptions of the purpose of practice in 'The relation of theory to practice in education'. In particular, he contrasted the 'laboratory' model, preferred by those who take a longer term vision of learning to teach and of teaching, with the 'apprentice' model, which takes a supply and demand approach to teacher education, and has a short term focus on meeting immediate classroom needs.

In the early twenty-first century the debates remain largely unchanged. As Zeichner (2014) recently noted, in the current reforms: two different visions of the role of teachers and teacher preparation are being advocated. On the one hand, some propose building or maintaining a professional teaching force and a system of teacher education that prepares teachers for professional roles and teaching careers (Darling-Hammond \& Bransford, 2005). Others believe that it is too costly to build and maintain a professional teaching force to teach everyone's children and have advocated preparing teachers of 'other people's children' as technicians to implement the teaching scripts with which they are provided, in the belief that the preparation these teachers receive and the subsequent scripting of instruction will lead to improvements in pupils' standardized test scores. Initial teacher education in this view (usually referred to as 'teacher training') should be very brief and take place mainly on the job. There is little expectation that these teachers will have teaching careers, and the system is designed to make it possible for these temporary teachers to be replaced in a few years by other narrowly trained teachers who also will leave the classroom in a few years (Rosen, 2003,p. $552)$.

\subsubsection{Multicultural Teacher Education}

Teacher Education is now passing through the age of changing (Ambe, 2006). There is a big paradigm shift from traditional teachers training to online teachers training and developing strategies for e-learning. Beside these advances, there is another debate of addressing culture issues in teacher education (Bannick \& Dam, 2007). Major educational reforms are unable to address the issues of multiculturalism and multicultural needs of future teachers. The review suggests that teacher education is problematic and that it is not possible to de contextualized multicultural teacher education from other problems of teacher education that arise in actual field (Boyle, 2005). While reviewing the work of previous multicultural teacher educators raises questions about the growth of the field and the quality of that growth. Current multicultural teacher education scholarship is beginning to balance the experimental and quasi-experimental and casual comparative research that has been prominent with a more qualitative case literature that uncovers the wisdom of practice. The increased use of autobiography, restructuring of field experiences, examination of situated and culturally specific pedagogies, and the return of the researcher to the classrooms of experts are resulting in the development of a critical multicultural teacher education (Bruna, 2007).

\subsubsection{Pedagogical Content Knowledge in Teacher Education}

Lee Shulman introduced the concept of Pedagogical Content Knowledge (PCK) to describe the knowledge that teachers use to transform particular subject matter for student learning, taking into account possible (mis) conceptions and learning difficulties. Shulman (1987) identified PCK as one of seven categories of teachers' knowledge defining it as "that special amalgam of content and pedagogy that is uniquely the province of teachers, their own special form of professional understanding" (p. 8). The other categories of teachers' knowledge included: (a) subject matter knowledge; (b) general pedagogical knowledge; (c) curriculum knowledge; (d) knowledge of learners and their characteristics; (e) knowledge of educational contexts; and (f) knowledge of educational ends, purposes, and values, and their philosophical and historical grounds. 
Cochran et al. (1993) identified that "PCK develops over time as a result of experience in many classroom settings with many students" (pp. 264-265). This means that inevitably, any initial teacher education program will be limited in its capacity to influence the PCK development of beginning teachers due to its (relatively) short duration. Developing PCK must be an ongoing process that begins in teacher education, continues with teaching practice and ongoing learning. Teacher education programs need to offer appropriate and coherent learning opportunities to assist pre-service teachers in their knowledge progression. This review points out aspects that can help build and strengthen PCK development.

\subsubsection{Pedagogical Reasoning in Teacher Education}

The foundations on which teaching is constructed hint at ways of thinking and knowing that shape pedagogy and illustrate why simplistic notions of teaching as telling and learning as listening do not suffice (Loughran, 2013). As a consequence, teaching is perhaps best understood as being problematic because it exists in what Sch (1983) described as the swampy lowlands where important but messy problems exist that cannot be simply resolved or technically managed. Teachers work with uncertainty in an 'indeterminate zone of practice' (Schø, 1987) in which professional knowledge develops in response to, and is informed by, the context.

There are major challenges that confront teacher educators in their teaching about teaching. However, those challenges also offer opportunities to lay bare the underpinnings of practiced through explicating pedagogical reasoning. Making pedagogical reasoning explicit through the teaching and learning of teaching has implications for both the thinking about, and development of the teacher educators' practice, and the same clearly applies for pre-service teachers. There is a great need to educate pre-service teachers in ways that extend beyond handing down teaching strategies that work. The work of teacher education is not about training, it should be an educative process that develops thoughtful, informed, and highly able professionals.

\subsubsection{Professionalizing Teacher Education}

Teacher quality has become the focus of intense policy activity in the past two decades across North America, Australasia, the United Kingdom, and other European countries, as well as across Asia, Africa and South America. Links between schooling and the economy are being made with teachers seen as key players in increasing a country's global competitiveness and neoliberal policies being seen as the necessary response such that globalization and neoliberalism have become "intimately entwined" (Furlong, 2013, p.30; Rizvi \& Lingard, 2010).

Although teacher education experiences should help future teachers develop these capacities and grow beyond what they originally brought with them, essentially they are only put to the test when they begin to teach. The process is not, or need not, be a solitary task for new teachers driven by a missionary sense of commitment to the education of others. It can, and should, be enhanced, improved and corrected as it unfolds, which is possible through support in such things as peer mentoring (e.g., the model offered by Tynjälä and Hekkinen, 2011 ) based on rigorous research about teaching and its conditions.

That some expected capacities to face the uncertainties of teaching must be fostered during initial teacher education (Bullough et al., 2008), and that it is not sufficient to infuse a sense of working for social justice if at the same time future teachers are not helped to enact appropriate curricular activities or learn about conditions in schools and school systems that work against those ideals (Agarwal et al., 2010; Loh \& Hu, 2014). In turn, policy makers and school authorities must understand the contradiction between pushing for high quality teacher education that prepares teachers to enact challenging forms of teaching and being responsive to pupils' needs, while further narrowing accountability structures based on standardized testing (Cherubini, 2009; Curry et al., 2008; Loh \& Hu, 2014 ).

\subsubsection{Hermeneutics: Three Basic Concepts}

Gadamer's notions of prejudice, tradition, and authority are directly related to a second strand of his thought, his interpretation of "interpretation." The word hermeneutics is derived from the Greek word for interpretation, hermenia. So, we can say that hermeneutics is the study of "interpretative theory." Arguably, Gadamer's (1995) main insight is that hermeneutics is at the heart of all inquiry --- not only within the human sciences but also the natural sciences. He therefore opposes the idea that method is the defining characteristic of human rationality. Instead, whatever methods the human and natural sciences may adopt in gathering information and these historically have been many and varied, all forms of human rationality and inquiry are essentially hermeneutic; for all are engaged in processes of interpretation, understanding, and application (Bannick \& Dam, 2007). Ricoeur (1993) places the notion of 
understanding at the heart of his account of hermeneutics. He said that traditionally, within hermeneutic theory, interpretation, understanding, and application had been considered as distinct and independent entities, but he argued that they were all moments in the single process of understanding. "Interpretation is not an occasional post facto supplement to understanding; rather, understanding is always interpretation, and hence interpretation is the explicit form of understanding" (p. 44). This is totally contrary to the Enlightenment view that there can be "objective understanding", freed from all prejudices and not contaminated by interpretation. Gadamer (1995) insisted that our prejudices, pre-judgments, our relationship to authority, and our being situated within traditions, were all part of the process of interpretation and coming to understand, and could not be bracketed out.

This idea comes close to Kuhn's (1970) notion that science always and inevitably operates within paradigms. The paradigms, "research programs" and "research traditions" (Laudan, 1976) are harbingers of prejudice, pre-judgment and authority, but they also provide the necessary theoretical framework within which the participant observer is situated in her/his quest for deeper understanding (Gollnick, 1995). Understanding is, therefore, not just one activity among others; rather it underlies all other human activities and is strongly implicated in the creation of meaning. "Meaning is always coming into being through the 'happening' of understanding" (Bernstein, 1983, p.139). Understanding, Gadamer (1995) argues, constitutes the very mode of our being in the world. Moreover, language is the medium of all understanding and all tradition. It should not be viewed simply as a tool of communication; rather it is the medium in which we live. Authentic understanding, therefore, cannot be detached from the interpreter for it is rooted in his or her very being, and is manifested in what he or she does, in practice. "In Gadamer's eyes, theory is... a kind of human practice. "Any genuine human practice is at the same time an expression of theory" (Wong, 1998, p. 108). Thus, on this account, there can be no radical divide between understanding (theory) and application (practice). What can be done is always and inevitably a combination of theoretical reflection and action (Dilthy, 1998).

\subsubsection{Hermeneutical Circle}

The hermeneutical circle of understanding is one in which interpretation is constantly played off against alternative interpretations in the process of deepening understanding. Of course, from the point of view of those who require hard data as the touchstone of truth, this will seem like a vicious circle in which we simply trade off interpretations without any chance of reaching the truth. To assume that, however, is to assume that all interpretations carry the same weight, but this relativist conclusion should be strongly resisted (Cochran, Smith, Davis, \& Fries, 2004).

\section{Discussion}

In the discussion section, first, the model will be presented and then, the suggested answer to the research question of the study will be given.

\subsection{An Inclusion-Based Hermeneutic Model (IBHM) for Teacher Education}

The overlap between the main issues in hermeneutics and teacher education can bring us to a model by which the "hermeneutics of teacher education" seems to be definable. Figure (1) illustrates how the "hermeneutics of teacher education" includes its inner components arranged in a top-down manner. Accordingly, a team work of "knowledge" and "skill" can result in the production of "curriculum" in which all aspects have been included and taken into account. Provided that a comprehensive curriculum exists as a result of expert team works regarding teacher education, the necessary condition will emerge named "cognition" which seems to be the very foundation of Teacher Education Hermeneutics. Here, the term "cognition" may not be directly attributed to human ability to distinguish various phenomena; however, it refers, here, to a collection of all those necessary elements of knowledge and skillfulness that are needed to provide a well-fit background of teacher education. This background seems to be lacked in many teacher training systems round the world about which scholars have written a lot. Figure (1) below, shows the hermeneutics of teacher education: 


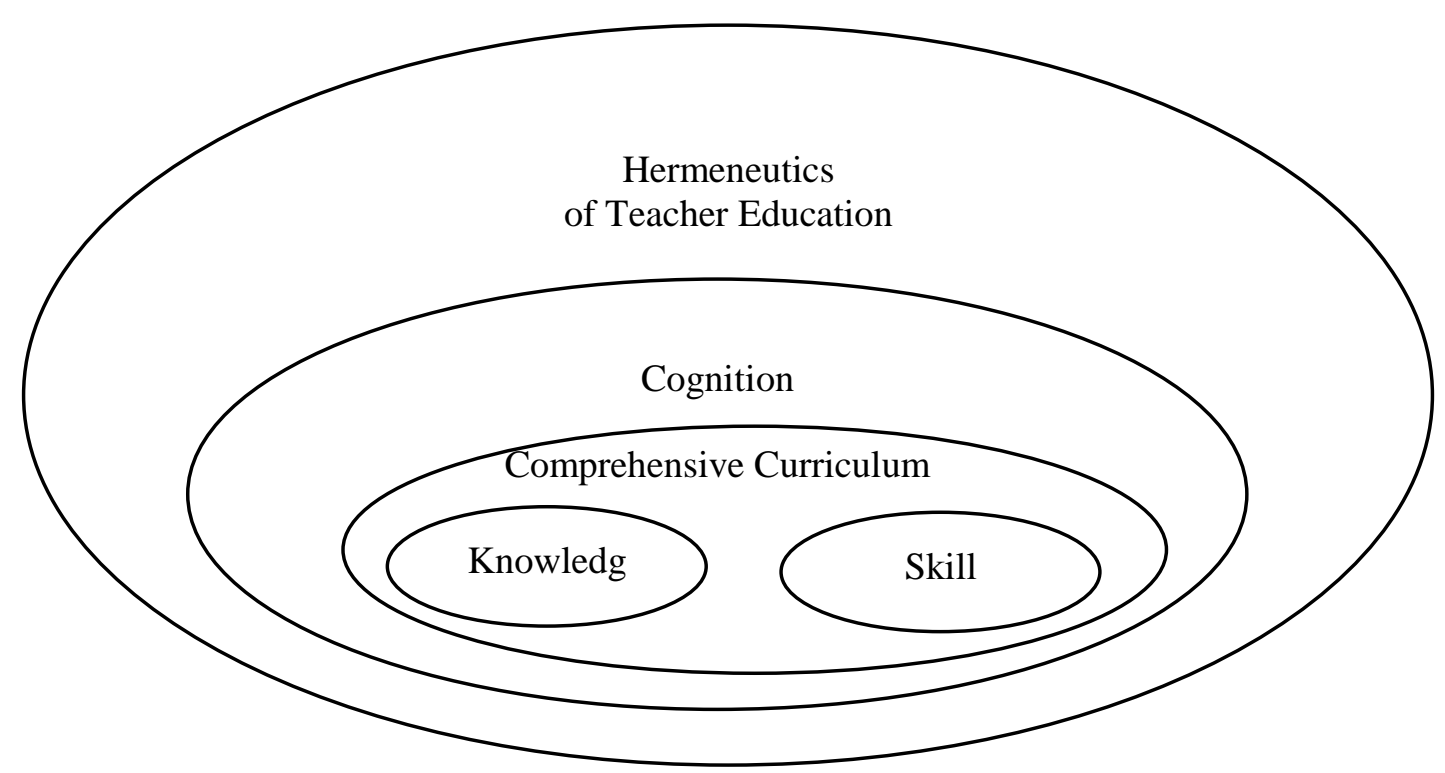

Figure 1. Inclusion-Based Hermeneutics Model for Teacher Education

\subsection{Suggested Answer to the Research Question}

The research question of the current study targeted the possibility of making a model that could be able to give an operational definition of teacher education from the standpoint of hermeneutics. Taking all concepts and the literature into account, now, it can be asserted that the answer to the research question is "Yes": the inclusion-based model seems to be capable of presenting an operational definition due to the fact that it encompasses a number of variables and put them together in a coherent meaningful way. As the model indicates, the general outer variable of "cognition" plays its role as a central core in the definition of teacher education and it itself covers other sub-variables.

\section{Conclusion}

Teacher education was discussed to be a field of study that has been investigated notably in recent times as the expectations for the pedagogy and the hopes for promotions in learning are so often connected to the high 'quality' of the foundations of teacher education. It seemed reasonable to argue that such issue could be as an implication of a particular orientation of teaching and learning that displays them as existing in a 'cause and effect' short-term, assessable with a linear relationship. Consequently, the concepts of "telling as teaching" and "listening as learning" will exist although not permanently. This will portray school teaching and learning simply as a 'banking model', through which 'rate of return' and 'substantive interest' are connected to curriculum designations via teaching approaches. Such a situation can lead to a sort of ambiguity in the reality of the nature of schooling, and also cause complexity about the reasonability that can be expected of teacher education programs as related to pre-services.

The real world of teaching and learning is ever evolving as the constantly changing relationship of teaching to learning and learning to teaching exists in a dynamic, symbiotic manner. Learning to teach is primarily a practical activity, informed by theoretical reflection. Also, that field experience should be the core component of initial teacher education programs, and all other components should be planned and conducted in relation to that core. This contrasts with the priority given to learning established educational theory in the theory-into-practice model that dominated teacher education for much of the twentieth century, but which came under increasing criticism in the 1990s (Carr, 1995; Kemmis, 1995; Wilkin \& Sankey, 1994).

The development of cultural competency is not an easy task. It requires multiple, broad based and varied opportunities, within school settings and beyond school settings, to interact with culturally, linguistically, and ethnically diverse communities over a prolonged period (Grant \& Secada, 1990). Novice teachers may benefit from field experiences 
that place them in multicultural settings and engender sharing with a diversity of people. Direct opportunities to live and teach in another culture generate multicultural competency, nurture positive cross-cultural attitudes and skills, and produce a deeper understanding of the need for cross-cultural competencies (Cooper, Beare, \& Thorman, 1990).

\section{References}

Agarwal. R., Epstein, S., Oppenheim, R., Oyler, C., \& Sonu, D. (2010). From ideal to practice and back again: Beginning teachers teaching for social justice. Journal of Teacher Education, $X X(X), 1-11$. doi: $10.1177 / 0022487109354521$

Ambe, E. B. (2006). Fostering multicultural appreciation in pre-service teachers through multicultural curricular transformation. Teaching \& Teacher Education: An International Journal of Research and Studies, 22(6), 690-699. https://doi.org/10.1016/j.tate.2006.03.005

Barnes, D. (1976). From communication to curriculum. Harmondsworth: Penguin.

Bannick, A., \& Van Dam, J. (2007). Bootstrapping reflection on classroom interactions: discourse contexts of novice teachers' thinking. Evaluation \& Research in Education, 20(2), 81-99. doi: 10.2167/eri400.0

Ben-Peretz, M., Kleeman, S., Reichenberg, R., \& Shimoni, S. (2013). Teacher educators as members of an evolving profession. Rowman \& Littlefield Education.

Bernstein, R. J. (1983). Beyond objectivism and relativism: Science, hermeneutics, and praxis. Oxford: Basil Blackwell.

Bourdieu, P., \& Passeron, J. C. (1977). Reproduction in education, society and culture (R. Nice, Trans.). London: Sage.

Boyd, P., Harris, K., \& Murray, J. (2011). Becoming a teacher educator: guidelines for induction. Higher Education Academy. Education Subject Centre. ESCalate.

Boyle-Baise, M. (2005). Preparing community-oriented teachers: reflections from a multicultural service-learning project. Journal of Teacher Education, 56(5), 446-458. doi: $\underline{10.1177 / 0022487105282113}$

Bransford, J. D., Brown, A. L., \& Cocking, R. R. (2000). How people learn: Brain, mind, experience, and school. Committee on Developments in the Science of Learning. Washington, DC: National Academies Press.

Bruna, K. (2007). Finding new words: how I use critical literacy in my multicultural teacher education classroom. Journal of Education for Teaching, 33(1), 115-118. https://doi.org/10.1080/02607470601098377

Bullough, R., Young, J. R., Hall-Kenyon, K. M., \& Draper, R. J. (2008). Cognitive complexity, the first year of teaching, and mentoring. Teaching and Teacher Education, 24(7), 1846-1858. doi: 10.1016/ j. tate.2008.02.001

Carr, W. (1995). For education: Towards critical educational inquiry. Buckingham: Open University Press.

Chaiklin, S., \& Lave, J. (1996). Understanding practice. Cambridge University Press.

Cherubini, L. (2009). New teachers' perceptions of induction: Insights into principled practices. The Alberta Journal of Educational Research, 55(2), 185-198. https://journalhosting.ucalgary.ca/index.php/ajer/article/view/55318

Cochran, K. F., DeRuiter, J. A., \& King, R. A. (1993). Pedagogical content knowing: An integrative model for teacher preparation. Journal of Teacher Education, 44(4), 263-272. https://doi.org/10.1177/0022487193044004004

Cochran-Smith, M., Davis, D., Fries, K., \& Banks, J. (2004). Multicultural teacher education: Research, practice and policy. Handbook of research on multicultural education.

Cooper, A., Beare, P., \& Thorman, J. (1990). Preparing teachers for diversity: A comparison of student teaching experiences in Minnesota and South Texas. Action in Teacher Education, 12(3), 1-4. https://doi.org/10.1080/01626620.1990.10734393 
Curry, M., Jaxon, K., Russel, J. L., \& Bicais, J. (2008). Examining the practice of beginning teachers' micropolitical literacy within professional inquiry communities. Teaching and Teacher Education, 24(3), 660-673. https://doi.org/10.1016/j.tate.2006.10.007

Darling-Hammond, L., \& Bransford, J. (2005). Preparing teachers for a changing world: What teachers should learn and be able to do. Jossey-Bass.

Darling-Hammond, L., \& Lieberman, A. (2012). Teacher education around the world. Changing policies and practices. London, Routledge.

Dewey, J. (1904). The relation of theory to practice in education. In C. A. McMurry (Ed.), The third yearbook of the national society for the scientific study of education. Part I. (pp. 9-30). Chicago, IL: The University of Chicago Press. https://archive.org/details/r00elationoftheorynatirich

Dilthy, W. (1998). The development of hermeneutics. Cambridge University Press.

Foucault, M. (1980). Power/knowledge. Pantheon Books.

Freire, P. (1972). Pedagogy of the Oppressed. Harmondsworth: Penguin.

Furlong, J. (2013). Education - An anatomy of the discipline. Routledge.

Gadamer, H. (1995). Truth and method (2nd ed.). New York: Continuum (Gollnick 1995).

Gollnick, D. (1995). National and state initiatives for multicultural education. In J. Banks, \& C. Banks (Eds.), Handbook of research on multicultural education. Old Tappan, NJ: Macmillan.

Grant, C. A., \& Secada, W. G. (1990). Preparing teachers for diversity. Handbook of research on teacher education. New York: Macmillan.

Habermas, J. (1998a). Actions, speech acts, linguistically mediated interactions, and the life world. In Jürgen Habermas, On the pragmatics of communication. Cambridge, Massachusetts: MIT Press, pp. 216-255 (first published in German in 1988).

Habermas, J. (1998b). Toward a critique of the theory of meaning. In Jürgen Habermas, On the pragmatics of communication. Cambridge, Massachusetts: MIT Press, pp. 277-306 (first published in German in 1988).

Haghighi, M., \& Rahimy, R. (2017). The effect of L2 minimal pairs practice on Iranian intermediate EFL learners' pronunciation accuracy. International Journal of Research in English Education, 2(1), 42-48. doi: $\underline{10.18869 / a c a d p u b . i j r e e .2 .1 .42}$

Hoban, G. F. (2005). The missing links in teacher education design. Springer. The Netherlands.

Kemmis, S. (1995). Theorizing educational practice. In W. Carr (Ed.), For education: Towards critical educational inquiry (pp. 2-17). Buckingham: Open University Press.

Kuhn, T. S. (1970). The structure of scientific revolutions. American Journal of Physics, II(7). doi: $10.7208 /$ chicago/9780226458106.001.0001

Lantolf, J. P. (2000). Sociocultural theory and second language learning. OUP. Oxford.

Lantolf, J. P., \& Appel, G. (1994). Vygostkian approaches to second language research. New Jersey Ablex.

Laudan, H. (1976). Progress and its problems: Towards a theory of scientific e growth. London: Routledge \& Kegan.

Lave, J., \& Wenger, E. (1991). Learning in doing: Social, cognitive, and computational perspectives. Situated learning: Legitimate peripheral participation. Cambridge University Press. https:// doi.org/ 10.1017/ CBO9780511815355

Leont'ev, A. N. (1981). The problem of activity in psychology. In Wertsch, J. V. (Ed.), The concept of activity in soviet psychology, 37-71. Armonk, NY: M. E. Sharpe.

Loh, J., \& Hu, G. (2014). Subdued by the system: Neoliberalism and the beginning teacher. Teaching and Teacher Education, 41, 13-21. https://doi.org/10.1016/j.tate.2014.03.005 
Loughran, J. (2010). Seeking knowledge for teaching: Moving beyond stories. Studying Teacher Education, 6(3), 221226. doi: $10.1080 / 17425964.2010 .518490$

Loughran, J. (2013). Pedagogy: Making sense of the complex relationship between teaching and learning. Curriculum Inquiry, 43(1). doi: $10.1111 /$ curi.12003

Mehrvarz Bahambari, N., \& Rahimy, R. (2016). School general English achievement and group-work: An investigation among Iranian junior High school students. International Journal of Research in English Education, 1(1), 43-50. http://ijreeonline.com/article-1-28-en.html

Murray, J., \& Male, T. (2005). Becoming a teacher educator: Evidence from the Field. Teaching and Teacher Education, 21(2), 125-142. https://doi.org/10.1016/j.tate.2004.12.006

Nashta Rahimi, S., \& Rahimy, R. (2017). The impact of teaching developmental grammatical errors on Iranian undergraduate translator trainees' L2 paragraph writing ability. International Journal of Research in English Education, 1(1), 25-33. doi: 10.18869/acadpub.ijree.2.1.25

Pourhossein Gilakjani, A. P. (2012). Visual, auditory, kinaesthetic learning styles and their impacts on English language teaching. Journal of Studies in Education, 2(1), 104-113. doi: 10.5296/jse.v2i1.1007

Ricoeur, P. (1993). Hermeneutics and the human sciences. Edited by John B, Cambridge University Press UK.

Rizvi, F., \& Lingard, B. (2010). Globalizing education policy. Routledge.

Rogoff, B. (2003). The cultural nature of human development. Oxford, England: Oxford University Press.

Rosen, A. (2003). For-profit teacher education. [Transcript] Chronicle of Higher Education, Colloquy Live.

Rosenblatt, L. M. (1938). Literature as exploration. NY: D. Appleton-Century.

Rosenblatt, L. M. (1978). The reader, the text, the poem: The transactional theory of the literary work. Carbondale IL: Southern Illinois University. Rosenblatt 1938, 1978.

Salomon, G. (1993). No distribution without individuals' cognition: A dynamic interactional view. In G. Salomon (Ed), Distributed cognitions: Psychological and educational considerations (pp. 111-138). Cambridge: Cambridge University Press.

Schleiermacher, F. (1938). Hermeneutik und Kritik. Volume VII (5th Ed.) Sage Publisher.

Schon, D. A. (1983). The reflective practitioner: How professionals think in action. New York: Basic Books.

Schon, D. (1987). Educating the reflective practitioner: Towards a new design for teaching and learning in the professions. San Francisco: Jossey-Bass.

Shulman, L. (1987). Knowledge and teaching: foundations of the new reform. Harvard Educational Review, 57(1), 1-23. https://doi.org/10.17763/haer.57.1.j463w79r56455411

Tynjälä, P., \& Heikkinen, H. L. T. (2011). Beginning teachers' transition from pre-service education to working life: Theoretical perspectives and best practices. Zeitschrift für Erziehungswissenschaft, 14, 11-33, 10.1007/s11618-011-0175-6

Vygotsky, L. S. (1978). Mind in society: The development of higher psychological processes. Cambridge, MA: Harvard University Press.

Vygotsky, L. S. (1986). Thought and language. Cambridge.

Wenger, E. (1998). Communities of practice: Learning, meaning, and identity. Cambridge University Press. https://doi.org/10.1017/CBO9780511803932

Wertsch, J. (1985). Vygotsky and the social formation of mind. Cambridge, MA: Harvard University Press.

Wertsch, J. V. (1991). Voices of the mind: A sociocultural approach to mediated action. Cambridge, MA: Harvard University Press.

Wilkin, M., \& Sankey, D. (1994). Collaboration and transition in initial teacher training. London: Kogan Page. 
Wong, W. C. (1998). The cave-metaphor reinterpreted. Journal of Basic Education, 7(2), 107-111.

Zeichner, K. (2014). The struggle for the soul of teaching and teacher education in the USA. Journal of Education for Teaching, 40(5), 551-568. doi: 10.1080/02607476.2014.956544 